liberal FAS. What sets the two groups apart is essentially the fact that the FAS is prepared to work for liberal change within the present political system, while the chief thrust of the movement is that the system should be changed. The radicals will argue that the conduct of science cannot be separated from the political and economic system in which it is practised (see box) and that the system should therefore bear the brunt of their analysis and criticism. In short, they preach subversion and socialist revolution-a factor which sets them apart from the bulk of the AAAS membership.

But the objectives of the Science For People movement are scarcely evident from their tactics at the AAAS meetings. They are consistently regarded as disruptive rather than constructive, and their tactics at the meeting addressed by Humphrey served chiefly to raise the hackles of even those participants who were also opposed to the Vietnam war. Although Herbert Fox, of the Northeastern University, and a prominent member of SESPA (Scientists and Engineers for Social and Political Action) said at a press conference "we are not interested in alienating the people at this meeting", that is often the chief product of their actions. To some extent, however, SESPA can claim credit for achieving a limited objective - making the AAAS into a rather more political body.

This year's meeting at Philadelphia contained many more political and social issues, ranging from a session on the new activism in science, to discussions of the contribution of science for peace and to sessions dealing with urban problems in Philadelphia. Spilhaus, who condemned the "childish graffiti" of the posters at the session addressed by Humphrey, admitted that "by some extremists we are pushed into the political arena". But he quickly added that if there were no dissent and no forthright discussion at the AAAS meetings "it would mean that we are not relevant". This shift in the content of some of the symposia is seen by many observers as a significant factor in the lessening of disruptive activity at the meeting this year.

Dr Barry Commoner, of Washington University and a board member of the AAAS, suggests, for example, that the association's policy of opening its doors to free discussion has had a positive effect on curbing disturbances, and Fox suggested that "the AAAS has found a way to discuss the same things we want to discuss".

But another important reason for the diminished activities of radical scientists at Philadelphia was the escalation of bombing in North Vietnam, which started on the first day of the meeting and provided a target for the radical scientists frustrations. All the main disruptions at the meetings were channelled towards a symposium on Value and Knowledge Requirements for Peace, and one day's activities was taken up by a march through the centre of Philadelphia to protest against the war. Frustration with the war was also shared by many of the less radical participants at the meeting, and the dissenters found themselves with considerable common ground among other members of the AAAS. (At one evening meeting, for example, a Vietnam Veteran was given leave to address the meeting to ask for contributions to the bail fund for his colleagues arrested in the Statue of Liberty. He was greeted with joyous applause and generous donations.)

The dissenters are, however, considerably out of tune with the AAAS as a body, and vigorously attack the way the organization is run and the way that the meetings are organized. A handout published by Science for the People at the conference, for example, states "The AAAS structures its sessions so that the all knowing luminaries of science can illuminate a passive audience with the latest technological solutions [to social problems]. But the role of the scientist should be to question the basic premises of the AAAS, to analyse the social context of scientific advance, and to further the political change necessary to resolve social problems. For the AAAS, success means more and continued privileges for scientists, it means that they continue to be well rewarded and secure priestly servants of corporate America".

It is debatable, however, whether much of the "passive audience" will have been illuminated by the meeting of the AAAS. There were few important scientific advances announced at the meeting - other vehicles for scientific communication are much more effective-and most of the other sessions charted familiar grounds. The overriding impression was that it had all been said before, and that the meeting serves chiefly as a social occasion to fill the dull days after Christmas. The most commonly heard complaint was that the meeting is really just a huge spectacle. As one professor's wife remarked during an evening session "the whole thing is a circus - a tweedy circus".

\section{A Radical View}

RADICAL dissenters at the AAAS annual meetings are frequently criticized for not stating their objectives and their beliefs, but for concentrating instead on confrontations with the scientific establishment. The following short extract is taken from an article describing the roots and the broad objectives of the Science for the People Movement. It was written by Bill Zimmerman, formerly Assistant Professor of Social Sciences at the University of Chicago, Len Radinsky and Mel Rothenberg, Associate Professor of Anatomy and Professor of Mathematics respectively at Chicago, and Bart Myers, Associate Professor of Psychology at Brooklyn College. The authors claim that the article was rejected by Science in spite of five referees' reports urging publication, and it was published by Science for the People and sold at the conference.

"In this society, at this time, it is not possible to escape the political implications of scientific work. The American ruling class has long had a commitment to science, not merely limited to short range practical applications, but based on the belief that science was good for the long-term welfare of American capitalism, and that what was good for American capitalism was good for humanity. This outlook was shared by the trustees of universities, the official leaders of US science, the administrators of government and private funding agencies. Further, they see this viewpoint as representing a mature social responsibility, morally superior to the 'pure search for truth' attitudes of some of the scientists. But they tolerate that ideology since it furthers their own aims and does not challenge their uses of science.

"We find the alternatives of 'science for science's sake' and 'science for progress and capitalism' equally unacceptable. We can no longer identify the cause of humanity with that of US capitalism. We don't have two governments, one which beneficently funds research and another which represses and kills in the ghetto, in Latin America and in Indochina. Nor do we have two corporate structures, manipulating for profit on the one hand while desiring social equality and justice on the other. Rather there is a single government-corporate axis which supports research with the intention of acquiring powerful tools, of both the hard and soft-ware varieties, for the pursuit of exploitive and imperial goals." 